\title{
STRATEGI LPTK DALAM PENGEMBANGAN KOMPETENSI PEDAGOGIK CALON GURU
}

\author{
Caraka Putra Bhakti \\ Bimbingan dan Konseling, Fakultas Keguruan dan Ilmu Pendidikan, Universitas Ahmad Dahlan, \\ caraka.pb@bk.uad.ac.id
}

\section{Ika Maryani}

Pendidikan Guru Sekolah Dasar, Fakultas Keguruan dan Ilmu Pendidikan, Universitas Ahmad Dahlan ika.maryani@pgsd.uad.ac.id

\begin{abstract}
Abstrak
Kemajuan suatu bangsa bergantung pada kualitas sumber daya manusianya. Kualitas sumber daya manusia dihasilkan oleh pendidikan yang berkualitas, Menghasilkan pendidikan berkualitas, guru menjadi faktor kunci keberhasilan. Guru merupakan faktor penentu keberhasilan penyelenggaraan pendidikan. Lembaga Pendidikan Tenaga Kependidikan (LPTK) mengemban tugas menyiapkan guru profesional, pendidik generasi bangsa masa depan. Guru merupakan jabatan profesional yang memberikan layanan ahli dan menuntut persyaratan kemampuan akademik, pedagogis, sosial, maupun profesional. Hasil uji kompetensi guru pada tahun 2015 menunjukkan kompetensi pedagogis guru rendah menempatkan LPTK sebagai lembaga yang paling bertanggungjawab dengan rendahnya kompetensi yang dimiliki. Diketahui bersama, bahwa guru merupakan produk LPTK, sehingga LPTK adalah lembaga yang lebih bertanggungjawab dengan kondisi tersebut. Masalah ini perlu dijadikan bahan evaluasi bagi LPTK dalam meningkatkan kualitas calon guru. Strategi-strategi yang dalam dilakukan dalam perbaikan mutu LPTK adalah 1) perbaikan kurikulum LPTK berbasis KKNI dan SNPT, 2) penguatan sistem pembelajaran yang efektif, 3) Pengembangan model pembelajaran berbasis student center learning, 4) penguatan program magang kependidikan, 5) penguatan pada mata kuliah dasar kependidikan, dan 6) Pengembangan mutu LPTK.
\end{abstract}

Kata Kunci: kompetensi pedagogik, calon guru, LPTK

\section{Abstract}

The progress of a nation depends on the quality of human resources. The quality of human resources generated by education quality, produce quality education, the teacher becomes a factor the key to success. Teachers are the critical success factors education. Education Workforce Education Institutions (LPTK) the task of preparing professional teachers, educators generation the nation's future. The teacher is a professional position which gives expert services and demanding requirements of academic skills, pedagogical, socially, and professionally. Test results of competence of teachers in 2015 pedagogical competence of teachers showed low as placing LPTK the institutions most responsible for the lack of competence owned. Known, that the teacher is a product LPTK, so LPTK is more responsible institution with the condition. This issue needs to be used as an evaluation for LPTK in improving the quality of teacher candidates. The strategies that can be performed in LPTK to quality improvement are 1) improvement of curriculum-based LPTK KKNI and SNPT, 2) strengthening effective learning system, 3) Development of a model-based learning student learning center, 4) strengthening educational internship program, 5) strengthening the courses basic education, and 6) Development LPTK quality.

Keywords: Pedagogical competency, prospective teacher, LPTK

\section{PENDAHULUAN}

Kemajuan suatu bangsa bergantung pada kualitas Sumber Daya Manusia nya. Kualitas SDM dihasilkan oleh pendidikan yang berkualitas, Menghasilkan pendidikan berkualitas, guru menjadi faktor kunci keberhasilan (Intan Ahmad, 2016). Guru merupakan faktor penentu keberhasilan penyelenggaraan pendidikan.

Beberapa studi bahkan menunjukkan bahwa kontribusi guru tetap tinggi meskipun dalam sistem pendidikan dan pendekatan pembelajaran yang bervariasi. Dalam konteks Indonesia, sayangnya, kita dihadapkan pada kenyataan bahwa kompetensi guru di Indonesia masih rendah. Hasil uji kompetensi guru tahun 2012 baik pada kompetensi pedagogik dan profesional.

Lembaga Pendidikan Tenaga Kependidikan (LPTK) mengemban tugas menyiapkan guru profesional, pendidik generasi bangsa masa depan. Guru merupakan jabatan profesional yang memberikan layanan ahli dan menuntut persyaratan kemampuan akademik, pedagogis, sosial, maupun profesional. Hasil uji kompetensi guru tahun 2015 terhadap 2.430.427 guru, menunjukkan ratarata nasional belum mencapai target, yakni 53,05 dari target 55. Nilai kemampuan profesional 54,77; sedangkan nilai rata-rata kompetensi pedagogik 48.94. Hanya ada 7 provinsi yang mencapai nilai rata-rata nasional, yakni Daerah Istimewa Yogyakarta $(62,58)$, Jawa Tengah $(59,10)$, DKI Jakarta $(58,44)$, Jawa Timur $(56,73)$, Bali 
(56,13), Bangka Belitung $(55,13)$, dan Jawa Barat $(55,06)$. Terendah rata-rata di salah satu provinsi di luar Jawa, hanya mencapai angka 41,96 (Kemendikbud, 2016). Hasil Uji Kompetensi Guru (UKG) dapat digunakan sebagai refleksi kualitas guru Indonesia. Sementara itu, Dirjen Guru dan Tenaga Kependidikan menyatakan bahwa target nilai rata-rata UKG tahun 2016 sebesar 65, sehingga menuntut upaya dan kerja keras guna pencapaiannya. Upaya peningkatan kualitas harus dilakukan, antara lain dengan penyiapan guru profesional melalui penyelenggaraan pendidikan penghasil guru yakni di LPTK. (http://www.kemdikbud.go.id/)

Direktur Jenderal Guru dan Tenaga Kependidikan (GTK) Kemendikbud, Surapranata (2015) mengatakan, jika dirinci lagi untuk hasil UKG untuk kompetensi bidang pedagogik saja, rata-rata nasional hanya 48,94, yakni berada di bawah standar kompetensi minimal (SKM), sebesar 55. Bahkan untuk bidang pedagogik ini, hanya ada satu provinsi yang nilainya di atas rata-rata nasional sekaligus mencapai SKM, yaitu DI Yogyakarta $(56,91)$. Hasil tersebut menunjukkan bahwa kemampuan pedagogik yakni terkait dengan 'cara mengajar' guru yang kurang baik

Hasil uji kompetensi yang tidak menggembirakan tersebut menempatkan LPTK sebagai lembaga yang paling bertanggungjawab dengan rendahnya kompetensi yang dimiliki. Diketahui bersama, bahwa guru merupakan produk LPTK, sehingga LPTK adalah lembaga yang lebih bertanggungjawab dengan kondisi tersebut. Salah satu kritik yang ditujukan pada perguruan tinggi adalah bahwa sistem dan proses pendidikannya kurang memperhatikan pembentukan keperibadian yang mandiri, krearif, inovatif dan demokratis (Azhar, 2009: 1).

Lulusan sesungguhya adalah akumulasi dari interaksi antara input dan proses pendidikan yang terjadi di LPTK. Untuk itu, penelaahan yang mendalam terhadap aspek input dan proses menjadi sangat penting. Dalam artikel ini, penulis akan memfokuskan pembahasan pada aspek proses LPTK.

Guru adalah salah satu jabatan profesional dalam bidang kependidikan. Sebagai jabatan, guru harus disiapkan melalui pendidikan dalam jangka waktu tertentu dengan seperangkat mata kuliah tertentu sesuai dengan jenjangnya. Pendidikan yang dimaksud adalah untuk mendidik calon guru yang mampu melaksanakan tugas secara profesional. Tugas profesional guru dapat dikelompokkan menjadi empat fungsi sekalipun di dalam praktik merupakan satu kesatuan yang saling terkait, mendukung dan memperkuat satu terhadap aspek yang lain. Empat fungsi yang dimaksud adalah; (1) guru sebagai pengajar, (2) guru sebagai pendidik, (3) guru sebagai pelatih, dan (4) guru sebagai pembimbing.
Kompetensi guru sebagaimana disebutkan dalam Undang-Undang Republik Indonesia Nomor 14 tahun 2005 Pasal 8 yaitu meliputi: (1) kompetensi pedagogik, (2) kompetensi kepribadian, (3) kompetensi sosial, dan (4) kompetensi professional yang diperoleh melalui pendidikan profesi. Kompetensi pedagogik merupakan kemampuan guru dalam pengelolaan pembelajaran, sedangkan kompetensi profesional merupakan kemampuan guru dalam menguasai pengetahuan bidang ilmu pengetahuan, teknologi, seni dan budaya yang diampunya. Keempat kompotensi guru tersebut dapat dilihat dalam pembelajaran. Ketika pembelajaran berlangsung, penguasaan keempat kompetensi tersebut akan dapat diketahui. Terutama pada kompetensi profesional dan kompetensi pedagogik yang akan lebih banyak berperan dalam pembelajaran. Hal ini berkaitan dengan kemampuan guru menguasai materi pembelajaran serta bagaimana mengajarkan materi tersebut kepada siswanya sehingga dapat diterima secara efektif (Winarno, 2003).

Menurut Mulyasa (2005) guru yang profesional adalah guru yang memiliki: (1) Kompetensi pedagogik, merupakan kemampuan yang berkenaan dengan pemahaman siswa dan pengelola pembelajaran yang mendidik, yang mencakup kemampuan perancangan dan pelaksanaan pembelajaran, evaluasi hasil belajar, dan pengembangan siswa untuk mengaktualisasikan berbagai potensi yang dimilikinya. (2) Kompetensi kepribadian, yakni kemampuan personal yang mencerminkan kepribadian yang mantap, stabil, dewasa, arif, dan berwibawa, menjadi teladan bagi peserta didik, dan berakhlak mulia. (3) Kompetensi sosial, berkenaan dengan kemampuan guru sebagai bagian dari masyarakat untuk berkomunikasi secara efektif dengan siswa, warga sekolah dan masyarakat

Kompetensi pedagogik merupakan hal penting yang harus dikuasai oleh para guru. Kerena kompetensi pedagogik merupakan syarat utama dalam menyelenggarakan pembelajaran yang efektif bagi para siswa untuk mencapai tujuan pendidikan. Kompetensi pedagogik menurut Undang-Undang No.14 Tahun 2005 tentang Guru dan Dosen pasal 1, ayat 10 adalah seperangkat pengetahuan, keterampilan, dan perilaku yang harus dimiliki, dihayati dan dikuasai oleh guru atau dosen dalam melaksanakan tugas keprofesionalannya.

Faktanya, sebagian guru belum memiliki kompetensi pedagogik secara utuh. Hasil penelitian Rachman (2013) tentang kompetensi pedagogis bahwa rata-rata SMP guru sains di kota Ternate adalah dalam kategori menengah (49,18\%), sedangkan sisanya, yaitu 34,34\%, berada dalam kategori baik, dan 16,39\% berada dalam kategori rendah. 
Hasil penelitian Syahruddin, dkk (2013) di ditemukan bahwa kompetensi pedagogik guru belum dikembangkan seperti yang diharapkan. Dengan demikian, dilaporkan bahwa kreativitas guru dibatasi oleh dominasi pemerintah. Disarankan bahwa untuk meningkatkan kualitas pengembangan profesional guru sangat diperlukan SBM (School Based Management).

Sejalan dari beberapa hasil penelitian tentang kompetensi pedagogik guru, penelitian terbaru yang dilakukan oleh Caraka Putra Bhakti, dkk (2016) tentang Profil Kompetensi Komunikasi Pedagogik Guru SMA di Provinsi Maluku Utara, menghasilkan data tentang kompetensi pedagogik guru ditinjau dari 13 kemampuan komunikasi pedagogis. Adapun berikut adalah tabel hasil penelitiannya.

Tabel 1. Kompetensi Komunikasi Pedagogik

\begin{tabular}{|c|c|c|c|c|c|c|}
\hline No & Kompetensi & 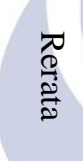 & $\begin{array}{l}\frac{3}{8} \\
\stackrel{2}{0}\end{array}$ & $\begin{array}{l}3 \\
\text { ¿ } \\
\text { ¿ }\end{array}$ & 意: & 光 \\
\hline 1 & $\begin{array}{l}\text { Kemampuan } \\
\text { membangun } \\
\text { rapport } \\
\text { (kedekatan) } \\
\text { dengan siswa }\end{array}$ & 5,48 & 6,5 & 0 & 0 & 10 \\
\hline 2 & $\begin{array}{l}\text { Kemampuan } \\
\text { memotivasi } \\
\text { siswa untuk } \\
\text { selalu semangat } \\
\text { dalam belajar }\end{array}$ & 6,00 & 7 & 8 & 0 & 10 \\
\hline 3 & $\begin{array}{l}\text { Kemampuan } \\
\text { menjelaskan } \\
\text { materi pelajaran } \\
\text { dengan jelas dan } \\
\text { mudah dipahami } \\
\text { oleh siswa }\end{array}$ & 5,84 & 7 & 8 & 0 & 10 \\
\hline 4 & $\begin{array}{l}\text { Kemampuan } \\
\text { menggunakan } \\
\text { dan } \\
\text { mengembangkan } \\
\text { media } \\
\text { pembelajaran } \\
\text { untuk } \\
\text { memperjelas } \\
\text { penyampaian } \\
\text { materi pelajaran? }\end{array}$ & 5,56 & 7 & 7 & 3 & 9 \\
\hline 5 & $\begin{array}{l}\text { Mampu } \\
\text { menghargai } \\
\text { pendapat siswa } \\
\text { pada kegiatan } \\
\text { pembelajaran? }\end{array}$ & 5,75 & 7 & 7 & 0 & 10 \\
\hline 6 & $\begin{array}{l}\text { Kemampuan } \\
\text { menyimak apa } \\
\text { yang diinginkan }\end{array}$ & 5,77 & 7 & 7 & 0 & 9 \\
\hline
\end{tabular}

\begin{tabular}{|c|c|c|c|c|c|c|}
\hline No & Kompetensi & 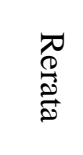 & 这. & 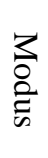 & 葛. & ב. \\
\hline & $\begin{array}{l}\text { siswa dalam } \\
\text { belajar }\end{array}$ & & & & & \\
\hline 7 & $\begin{array}{l}\text { Kemampuan } \\
\text { merangkum } \\
\text { materi yang telah } \\
\text { dijelaskan }\end{array}$ & 5,63 & 7 & 7 & 0 & 10 \\
\hline 8 & $\begin{array}{l}\text { Kemampuan } \\
\text { menciptakan } \\
\text { suasana yang } \\
\text { hangat dan } \\
\text { antusias di dalam } \\
\text { maupun di lua } \\
\text { kelas }\end{array}$ & 5,54 & 7 & 0 & 0 & 9 \\
\hline 9 & $\begin{array}{l}\text { Kemampuan } \\
\text { menjadi } \\
\text { pemodelan } \\
\text { (contoh perilaku) } \\
\text { dalam } \\
\text { pengembangan } \\
\text { karater siswa }\end{array}$ & 5,42 & 7 & 7 & 0 & 9 \\
\hline 10 & $\begin{array}{l}\text { Kemampuan } \\
\text { menciptakan } \\
\text { pembelajaran } \\
\text { yang berpusat } \\
\text { pada siswa }\end{array}$ & 4,87 & 7 & 0 & 0 & 8 \\
\hline 11 & $\begin{array}{l}\text { Kemampuan } \\
\text { melakukan } \\
\text { pengkondisian } \\
\text { kelas untuk } \\
\text { menciptakan } \\
\text { suasana belajar } \\
\text { yang efektif }\end{array}$ & 5,23 & 7 & 8 & 0 & 9 \\
\hline 12 & $\begin{array}{l}\text { Mampu } \\
\text { memberikan } \\
\text { pertanyaan } \\
\text { terbuka dan } \\
\text { tertutup bagi } \\
\text { siswa dalam } \\
\text { mengungkap } \\
\text { pemahaman } \\
\text { siswa dalam } \\
\text { pembelajaran }\end{array}$ & 5,25 & 7 & 0 & 0 & 9 \\
\hline 13 & $\begin{array}{l}\text { Kemampuan } \\
\text { melakukan } \\
\text { variasi metode } \\
\text { pembelajaran }\end{array}$ & 5,17 & 7 & 8 & 0 & 9 \\
\hline
\end{tabular}

Dari 13 kemampuan di atas, paling tinggi kemampuan memotivasi siswa untuk selalu semangat dalam belajar $(6,0)$. Pada urutan kedua, adalah kemampuan menjelaskan materi pelajaran dengan jelas dan mudah dipahami oleh siswa dengan skor rerata sebesar 5,84. Pada urutan ketiga, adalah kemampuan menyimak apa yang diinginkan siswa dalam belajar 
dengan nilai rerata sebesar 5,77. Hal ini menunjukkan bahwa guru sudah memiliki kemampuan dalam memotivasi siswa, menjelaskan materi pelajaran dan menyimak siswa, namun sebagian lagi belum.

Tiga kemampuan yang memiliki skor terendah adalah kemampuan menciptakan pembelajaran yang berpusat pada siswa $(4,87)$, kemampuan melakukan variasi metode pembelajaran $(5,17)$, kemampuan melakukan pengkondisian kelas untuk menciptakan suasana belajar yang efektif $(5,23)$. Hal ini menunjukkan bahwa guru belum secara maksimal menjalankan tugas dan materi yang terstuktur pada para siswa. Selanjutnya, kemampuan rendah lainnya berkaitan dengan manajemen kelas yakni bagaimana membuat proses pembelajaran menjadi efektif dan mengkondisikan kelas. Guru belum juga mampu memberikan pertanyaan terbuka dan tertutup bagi siswa dalam mengungkap pemahaman siswa dalam pembelajara. Kompetensi ini terkait juga dengan kemampuan penguasaan materi dan kreativitas guru dalam mengajar. Penguatan kompetensi pedagogik calon guru perlu dilakukan serangkaian aktivitas pengembangan di LPTK untuk pengembangan kompetensi pedagogis bagi calon guru.

\section{PEMBAHASAN}

\section{A. Kurikulum LPTK}

Sosok lulusan LPTK harus merujuk kepada standar nasional yang disesuaikan dengan karakteristik pendidikan tinggi yang wajib menyelenggarakan Tridharma Perguruan Tinggi meliputi pendidikan, penelitian, dan pengabdian kepada masyarakat. Cakupan standar pendidikan tinggi lebih luas dari delapan standar yang ditetapkan dalam Peraturan Pemerintah RI Nomor 19 Tahun 2005 tentang Standar Nasional Pendidikan. Peraturan Presiden Nomor 8 tahun 2012, tentang Kerangka Kualifikasi Nasional Indonesia (KKNI) merupakan pernyataan kualitas sumber daya manusia Indonesia. Perguruan tinggi sebagai penghasil sumber daya manusia terdidik perlu merancang, melaksanakan, dan mengukur kesetaraan kemampuan lulusan dengan kualifikasi KKNI dan standar kompetensi guru yang ditetapkan. Tantangan besar bagi LPTK untuk mewujudkan profil lulusan calon guru yang profesional (strata 1), diantaranya harus menyusun kurikulum sebagai pedoman penyelenggaraan pendidikan yang harus mampu menjamin ketercapaian kompetensi lulusan sesuai kualifikasi KKNI level 6. Tingkat kemampuan yang dinyatakan dalam rumusan capaian pembelajaran (learning outcomes) harus didasarkan dengan jenjang kualifikasi KKNI.

Kerangka Kualifikasi Nasional Indonesia, yang selanjutnya disingkat KKNI, Pasal 1 (1) dijelaskan bahwa KKNI adalah kerangka penjenjangan kualifikasi kompetensi yang dapat menyandingkan, menyetarakan, dan mengintegrasikan antara bidang pendidikan dan bidang pelatihan kerja serta pengalaman kerja dalam rangka pemberian pengakuan kompetensi kerja sesuai dengan struktur pekerjaan di berbagai sektor. Tidaklah mudah mengimplementasikan KKNI ini ke dalam kurikulum pendidikan guru. Mengingat profesi guru adalah profesi yang akan mendewasakan peserta didik untuk menjadi manusia dewasa yang cerdass dan berkepribadian. Terkait dengan hal ini, terdapat dua hal penting dalam mengimplementasikan Kerangka Kualifikasi Nasional Indonesia ke dalam Program Pendidikan Profesi Guru.

Pertama, sesuai dengan amanah Peraturan Pemerintah No. 74 Tahun 2008 tentang Guru yang menyatakan bahwa guru harus berkualifikasi S1/D IV, dan guru harus memiliki sertifikat profesi pendidik, implementasinya perlu disesuaikan antara model penyiapan guru profesional, kurikulum, dan kaitannya dengan jenjang kualifikasi pada KKNI. Jika dikaitkan dengan penjenjangan kualifkasi dalam KKNI, bahwa guru harus berkualifikasi adalah jenjang 6 (enam), dan memiliki sertifikat profesi pendidik yang diperoleh melalui pendidikan profesi adalah jenjang 7 (tujuh). Berdasarkan kajian empirik, akademik, dan perundangan, maka implementasi KKNI dalam pendidikan profesi guru dapat diterapkan dengan dua model, yaitu secara berlapis, artinya menyelesaikan level 6 (S-1) terlebih dahulu baru mengikuti pendidikan profesi (level 7), dan dapat dilaksanakan secara terintegrasi antara pendidikan akademik dan pendidikan profesi (bersamaan antara level 6 dan 7) namun tetap memposisikan kajian level 7 pada semester akhir.

Kedua, terkait dengan capaian pembelajaran dalam pendidikan profesi guru, akan berimplikasi pada sistem pembelajaran. Sistem pembelajaran dalam PPG tidak lagi seperti perkuliahan pada pendidikan akademik, tetapi untuk menyiapkan calon guru profesional dilaksanakan dengan sebanyak mungkin workshop pengembangan perangkat pembelajaran dan praktik untuk mewujudkan kompetensi pedagogik, profesional/penguasaan bidang studi, sosial, dan kepribadian yang disesuaikan deskripsi generik jenjang 7 pada KKNI.

Di samping itu, amanat Undang-Undang Nomor 12 Tahun 2012 tentang Pendidikan Tinggi, pada Pasal 35 ayat 2 dinyatakan bahwa Kurikulum Pendidikan - Tinggi dikembangkan oleh setiap Perguruan Tinggi dengan mengacu pada Standar Nasional Pendidikan Tinggi untuk setiap program studi yang mencakup pengembangan kecerdasan intelektual, akhlak mulia, dan keterampilan. Rambu-rambu penyelenggaraan pendidikan yang diatur dalam Standar Nasional Pendidikan Tinggi Permenristekdikti No. 44 Tahun 2015 harus dipahami dan diimplementasikan dalam berbagai kebijakan lingkup lembaga pendidikan tinggi, hingga lingkup pembelajaran yang harus dilaksanakan dosen dalam perkuliahan.

B. Sistem Pembelajaran Pendidikan Akademik Menurut Bintoro (2014) sistem pembelajaran dalam pendidikan akademik dengan memperhatikan beberapa prinsip sebagai berikut: 
1. Keaktifan peserta didik

Proses pembelajaran diarahkan pada upaya untuk mengaktifkan peserta didik, bukan dalam arti fisik melainkan dalam keseluruhan perilaku belajar. Keaktifan ini dapat diwujudkan antara lain melalui pemberian kesempatan menyatakan gagasan, mencari informasi dari berbagai sumber dan melaksanakan tugas-tugas yang merupakan aplikasi dari konsep-konsep yang telah dipelajari.Pendidikan tinggi LPTK, sebagai pendidikan tingi yang mengemban misi untuk menghasilkan calon pendidik yang unggul, yaitu pendidik yang dapat melaksanakan tugas pembelajaran dan pendidikan yang ditandai dengan kemampuan melaksanakan pembelajaran yang aktif, inovatif, dan menyenangkan atau active learning in school (ALIS), harus disiapkan melalui satu sistem pendidikan yang bermutu. Proses pendidikan calon pendidik di LPTK harus dirancang dan dikembangkan berdasarkan prinsip active learning in higher education (ALIHE) atau student active learning (SAL).

2. Higher order thinking

Pengembangan sistim pembelajaran yang berorientasi pada kemampuan berfikir ingkat tinggi (higher order thinking), meliputi berfikir kritis, kreatif, logis, reflektif, pemecahan masalah dan pengambilan keputusan.

3. Dampak pengiring

Di samping diarahkan pada pencapaian dampak instruksional (instructional effects), proses pembelajaran diharapkan mengakomodasi upaya pencapaian dampak pengiring (nurturant effects). Upaya ini akan membantu pengembangan sikap dan kepribadian peserta didik sebagai calon guru. Sebagai contoh, pembelajaran sains secara tidak langsung akan menanamkan sikap ilmiah kepada peserta didik, penerapan strategi pembelejaran melalui diskusi, secara tidak langsung akan membentuk kemampuan komunikasi, menghargai pendapat orang lain, mendengarkan pendapat orang, dsb.

4. Pemanfaatan Teknologi Informasi

Keterampilan memanfaatkan multi media dan teknologi informasi perlu dikembangkan dalam semua perkuliahan, baik untuk mengembangkan pengetahuan dan keterampilan maupun sebagai media pembelajaran.

5. Pembelajaran Kontekstual

Dalam melaksanakan pembelajaran, konsepkonsep diperoleh melalui pengalaman dan kenyataan yang ada di lingkungan sehari-hari. Pengenalan lapangan dalam bidang pembelajaran dilakukan sejak awal, tidak hanya menjelang akhir program, melalui kunjungan ke sekolah pada waktu-waktu tertentu, hingga pelaksanan Program Pengalaman Lapangan. Kegiatan dirancang dan dilaksanakan sebagai tugas perkuliahan.
6. Penggunaan strategi dan model pembelajaran yang inovatif dan bervariasi dalam mengaktifkan peserta didik.

7. Belajar dengan berbuat.

Prinsip learning by doing tidak hanya diperlukan dalam pembentukan keterampilan, melainkan juga pada pembentukan pengetahuan dan sikap. Dengan prinsip ini, pengetahuan dan sikap terbentuk melalui pengalaman dalam menyelesaikan kegiatan-kegiatan yang ditugaskan termasuk mengatasi masalahmasalah yang dihadapi di lapangan.

C. Pembelajaran Student Center Learning (SCL)

1. Konsep Pembelajaran Student Center Learning (SCL)

Harsono (2008) menyebutkan ide dasar dari student-centered is student might not only choose what to study, but how and why that topic might be an interesting one to studŷे. SCL merupakan strategi pembelajaran yang menempatkan mahasiswa sebagai subyek/peserta didik yang aktif dan mandiri, dengan kondisi psikologik sebagai adult learner, bertanggung jawab sepenuhnya atas pembelajarannya, serta mampu belajar beyond the classroom. Dengan prinsip-prinsip ini maka para mahasiswa diharapkan memiliki dan menghayati jiwa life-long learner serta menguasai hard skills dan soft skills yang saling mendukung. Di sisi lain, para dosen beralih fungsi menjadi fasilitator, termasuk sebagai mitra pembelajaran, tidak lagi sebagai sumber pengetahuan utama

2. Model-Model Pembelajaran

Keberhasilan pada abad ke-21 akan tergantung terutama pada sejauh mana kita mengembangkan keterampilan-keterampilan yang tepat untuk menguasai kekuatan, kecepatan, kompleksitas, dan ketidakpastian, yang saling berhubungan satu sam lain. Semuanya tergantung pada diri kita. Kecepatan dunia berubah menuntut dan mensyaratkan kemampuan belajar yang lebih cepat. Kompleksitas dunia yang terus meningkat juga menuntut kemampuan yang sesuai untuk menganalisis setiap situasi secara logis dan memecahkan masalah secara kreatif (Rose dan Nicholl, 2002). Menurut Endrotomo (2013) Adanya pergeseran paradigma dalam pembelajaran (cara memandang pengetahuan, proses belajar, dan mengajar) Dunia kerja sangat membutuhkan softskills disamping hardskills Tidak semua hal bisa diajarkan, tapi semua hal bisa dipelajari. Belajar bukan hanya menerima pengetahuan, bersifat pasif-reseptif namun belajar adalah mencari dan mengkonstruksi pengetahuan lewat berbagai strategi. 
D. Program Magang Kependidikan

Pendidikan Guru berjenjang dari pendidikan Akademik (S-1) dan Pendidikan Profesi sebuah kesatuan yang tidak terpisah. Dalam pengembangan jati diri calon guru pengenalan dunia sekolah sejal awal, di level pendidikan akademik disebut magang, sedang di pendidikan profesi disebut PPL (Program Pengalaman Lapangan). Penelitian ini berfokus pada program magang kependikkan

Menurut panduan penyusunan kurikukum LPTK (Dikti,2012:34), subtansi tahapan program magang sebagai berikut :

\section{a. Magang 1}

1) Pengamatan langsung kultur sekolah.

2) Pengamatan untuk membangun kompetensi dasar Pedagogik, Kepribadian, dan Sosial.

3) Pengamatan untuk memperkuat pemahaman peserta didik.

4) Pengamatan langsung proses pembelajaran di kelas.

5) Refleksi hasil pengamatan proses pembelajaran.

6) Magang 1 diberikan bobot setara dengan 1 sks

b. Magang 2

1) Menelaah kurikulum dan perangkat pembelajaran yang digunakan guru.

2) Menelaah strategi pembelajaran.

3) Menelaah sistem evaluasi.

4) Merancang RPP

5) Mengembangkan media pembelajaran

6) Mengembangkan bahan ajar

7) Mengembangkan perangkat evaluasi.

8) Magang 2 diberikan bobot setara dengan 1 sks

c. Magang 3

1) Mencoba mengajar dengan bimbingan melekat guru dan dosen pembimbing, dengan tujuan merasakan langsung proses pembelajaran, pemantapan jati diri pendidik, bukan untuk keterampilan ws, bukan PPL

2) Melaksanakan tugas-tugas pendampingan peserta didik dan kegiatan ekstra kurikuler

3) Magang 3 diberikan bobot setara dengan 2 sks

Seiring perkembangan telah terjadi pergeseran model kurikulum pendidikan guru. Seseorang disebut Profesional jika telah menempuh pendidikan S1 dan pendidikan profesi (UUGD No.14 tahun 2005). Dalam pengembangan kompetensi profesionalnya perlu dipersiapkan secara bermutu. Dalam pembentukan kompetensi dan jiwa pendidik tidak serta merta terbentuk hanya dengan pemberian pengalaman sesaat dan hanya diujung proses pendidikan. Oleh karena itu, pada struktur kurikulum pendidikan akademik untuk calon guru harus menempatkan pemajanan awal (early exposure), yaitu pemberian pengalaman sedini mungkin kepada calon guru dengan magang atau internship di sekolah secara berjenjang. Dalam konteks ini pedagogi harus dipahami sebagai konsep yang merujuk pada dua aspek belajar. Pertama, pedagogi berkaitan dengan apa dan bagaimana peserta didik belajar; kedua, pedagogi berkaitan dengan bagimana (calon) guru sebagai pembelajar belajar tentang mengajar dan membentuk keahliannya sebagai seorang profesional.

Pemajanan awal (earlier exposure) para calon guru pada situasi pembelajaran di kelas/sekolah. (1) tahapan observasi terhadap praktik pembelajaran di kelas dan aspek-aspek yang terkait dengan pengelolaan dan implementasi kurikulum sekolah; (2) tahapan mengkaji aspek praktis kurikulum sekolah dan penerapnanya di kelas yang dikaitkan dengan perkuliahan kedua kelompok mata kuliah tersebut; (3)tahap penyusunan rancangan pembelajaran dan implementasinya berdasarkan keterkaitan antara yang diperoleh diperkuliahan dengan yang dipelajari di sekolah; dan ,(4) melaksanakan praktik pembelajaran di kelas sebagai asisten guru (Dikti,2012).

Desain Pendidikan Profesional Guru harus mencerminkan gagasan bahwa learning to teach melibatkan apa yang disebut practice in practice. Teori yang diajarkan dalam perkuliahan hendaknya dicoba dipraktikkan di lapangan dan praktik yang terjadi di lapangan dikaji dasar teoretiknya, sehingga terjadi hubungan saling menguatkan antara teori dan praktik lapangan. Perpaduan antara perkuliahan dan kerja lapangan ini memberi kesempatan untuk mengaitkan teori dan praktik. Artinya, proses perkuliahan diisi dengan materi substansial dan penyampaiannya dipetik dari pengalaman praktik untuk selanjutnya dimanfaatkan guna memberikan tuntunan kepada para calon guru tentang bagaimana seharusnya bekerja di sekolah.

Pengalaman praktik akan sangat efektif jika didukung oleh dosen pembimbing dan guru pamong yang berpengalaman sebagai model. Kerja sama antara para guru pamong dan dosen pembimbing sangat bermanfaat untuk membimbing mahasiswa 
calon guru, karena kepakaran mengajar itu diperoleh melalui waktu yang panjang.

Penelitian Sailaja Chennat, 2014. model magang untuk pendidikan guru di India melibatkan orientasi teoritis singkat diikuti dengan periode 3 sampai 5 tahun mengajar diawasi di sekolah di bawah pembimbing guru, penekanan lebih pada praktik reflektif berdasarkan perspektif pada peserta didik dan konteksnya. Karakteristik sekolah magang sesuai bidnag kelimuan, lama waktu magang empat hari seminggu untuk jangka waktu minimal 12-20 minggu termasuk satu minggu dengan supervisi penuh dari guru pembimbing, dan kelas pendidikan guru berbasis Research Projects.

Parveen (2012) hasil penelitiannya menunjukkan program magang pendidikan menunjukkan bahwa siswa-guru melihat program magang sebagai kesempatan nyata untuk memperbaiki dan meningkatkan keterampilan mengajar mereka di sekolah yang sebenarnya. Hasil wawancara mendalam dengan kepala sekolah mengungkapkan program magang adalah sangat penting dan memiliki dampak positif pada kinerja siswa-guru.

Vaillant (2013) memaparkan tentang banyak temuan tentang ketidakpuasan model pendidikan guru, hasil studi leteratur menunjukkan perlu lima faktor yang perlu diperhatikan dalam reformasi pendidikan guru yaitu pembentukan standar kompetensi pendidikan guru, praktik mengajar berbasis scientific learning, kejelasan kualifikasi lulusan, pengemabangan literatur dan pusat belajar pendidikan, dan adanya penilaian ekternal untuk monitoring kualitas guru.

E. Mata Kuliah Dasar Kependidikan

LPTK hendaknya memperbaiki kondisi kurikulum pendidikan calon guru maka idealnya fokus kepada komponen item uji kompetensi guru yang sudah menjadi kebijakan nasional di Indonesia untuk mendongkrak kualitas guru di negeri ini. Salah satu cara dapat dilakukan adalah mencermati silabus mata kuliah dasar kependidikan (MKDK) dengan menganalis cakupan materi dan ketepatan materi MKDK yang mampu menunjang peningkatan kompetensi pedagogik guru sebagai core dari kompetensi guru secara keseluruhan. Idealnya, setiap komponen kompetensi pedagogik dalam UKG, masing-masing diturunkan menjadi mata kuliah dasar kependidikan di LPTK dan mata kuliah di program studi.

Dalam tataran universitas, mata kuliah dasar kependidikan (MKDK) perlu mengakomodasi komponen-komponen UKG yang terdiri atas 7 (tujuh) aspek, yaitu: (1) menguasai karakteristik peserta didik, (2) menguasai teori belajar dan prinsip-prinsip pembelajaran yang mendidik, (3) pengembangan kurikulum, (4) kegiatan pembelajaran yang mendidik, (5) pengembangan potensi peserta didik, (6) komunikasi dengan peserta didik, (7) penilaian dan evaluasi. Komponen tersebut dapat dituangkan ke dalam empat mata kuliah dengan dengan bobot SKS dan deskprisi sebagai berikut:

1. Psikologi Pendidikan (2 SKS)

Mata kuliah ini mempelajari hakikat perkembangan peserta didik, belajar dan pembelajaran yang mendidik, pengembangan potensi peserta didik, pembelajaran sebagai proses komunikasi dan evaluasi program pembelajaran.

2. Pengembangan Kurikulum dan Pembelajaran (2 SKS)

Mata kuliah ini mempelajari hakikat kurikulum, komponen kurikulum, landasan dan prinsip kurikulum, model pengembangan kurikulum, evaluasi kurikulum, pendekatan dan model pembelajaran, media pembelajaran,desain pembelajaran, evaluasi hasil belajar, dan pengembangan perangkat pembelajaran.

3. Pengantar Ilmu Pendidikan (2 SKS)

Mempelajari tentang hakikat manusia dan pendidikan, lingkungan pendidikan, faktorfaktor pendidikan, landasan Pendidikan, Aliran Pendidikan, sistem pendidikan nasional, permasalahan pendidikan, dan kebijakan pendidikan nasional.

4. Pengembangan Profesi Guru (2 SKS)

Mata kuliah ini mempelajari organisasi sekolah, kepemimpinan sekolah, supervisi akademik, guru sebagai pendidik profesional, kegiatan kolektifitas guru, pengembangan profesi guru, pengelolaan kelas, dan guru sebagai konselor.

F. Pengembangan Mutu LPTK

LPTK memiliki tanggung jawab mempersiapkan calon sarjana yang siap pakai, memiliki kompetensi yang diperlukan di lapangan pekerjaan. Selain itu kurikulum LPTK juga harus dirancang sesuai kebutuhan pasar. Untuk meningkatkan kualitas LPTK, Perlu kajian serius dan mendalam tentang reposisi, penataan dan penguatan kelembagaan LPTK. Disamping pula diperlukan landasan hukum untuk memperkuat jati diri LPTK.

Untuk menentukan kelayakan secara kelembagaan, standar kelembagaan digunakan untuk sebagai tolak ukur dalam proses evaluasi 
kelembagaan tersebut. Lembaga yang telah memenuhi standar tersebut disebut lembaga yang terakreditasi atau accredited in teacher education institution. Berikutnya Slamet (dalam Azhar (2011:79) mengatakan bahwa ada empat usaha mendasar yang harus dilakukan untuk menghasilkan mutu yang baik, yaitu:

1. Menciptakan situasi win-win solution, bukan kalah-menang diantara pihak yang berkepentingan dengan lembaga pendidikan (stakeholder). Terutama antara pimpinan lembaga dengan staf lembaga harus terjadi kondisi yang saling menguntungkan satu sama lain dalam meraih mutu produk /jasa yang dihasilkan oleh lembaga pendidikan.

2. Perlu dikembangkan motivasi instrinsik pada setiap orang yang terlibat dalam proses meraih mutu. Setiap orang dalam lembaga pendidikan harus tumbuh motivasi bahwa hasil kegiatannya mencapai mutu tertentu yang meningkat terus menerus terutama sesuai kebutuhan dan harapan pengguna.

3. Setiap pimpinan harus berorientasi pada proses dan hasil jangka panjang. Penerapan manajemen mutu terpadu dalam pendidikan bukanlah suatu proses perubahan jangka pendek.

4. Dalam menggerakkan segala kemampuan lembaga pendidikan untuk mencapai mutu yang ditetapkan, haruslah dikembangkan adanya kerjasama antar unsur-unsur pelaku proses mencapai hasil mutu. Semuanya harus bekerjasama dantidak dapat dipisahkan satu sama lain untuk menghasilkan mutu sesuai yang diharapkan.

\section{PENUTUP}

\section{Simpulan}

Kemajuan suatu bangsa bergantung pada kualitas sumber daya manusianya. Kualitas sumber daya manusia dihasilkan oleh pendidikan yang berkualitas, Menghasilkan pendidikan berkualitas, guru menjadi faktor kunci keberhasilan. Guru merupakan faktor penentu keberhasilan penyelenggaraan pendidikan. Lembaga Pendidikan Tenaga Kependidikan (LPTK) mengemban tugas menyiapkan guru profesional, pendidik generasi bangsa masa depan.

Guru merupakan jabatan profesional yang memberikan layanan ahli dan menuntut persyaratan kemampuan akademik, pedagogis, sosial, maupun profesional. Hasil uji kompetensi guru pada tahun 2015 menunjukkan kompetensi pedagogis guru rendah menempatkan LPTK sebagai lembaga yang paling bertanggungjawab dengan rendahnya kompetensi yang dimiliki. Diketahui bersama, bahwa guru merupakan produk LPTK, sehingga LPTK adalah lembaga yang lebih bertanggungjawab dengan kondisi tersebut. Masalah ini perlu dijadikan bahan evaluasi bagi LPTK dalam meningkatkan kualitas calon guru. Adapun beberapa strategi dalam perbaikan mutu LPTK dalam pengembangan kompetensi pedagogik adalah 1) perbaikan kurikulum LPTK berbasis KKNI dan SNPT, 2) penguatan sistem pembelajaran yang efektif, 3) Pengembangan model pembelajaran berbasis student center learning, 4) penguatan program magang kependidikan, 5) penguatan pada mata kuliah dasar kependidikan, dan 6) Pengembangan mutu LPTK.

\section{Saran}

Dalam pengembangan kompetensi pedagogik calon guru, LPTK berperan penting dengan mencetak guru profesional. Pendidik profesional bermula dari proses pendidikan yang bermutu. Pembangunan pendidikan bermutu dimulai dari penataan kualitas dosen, penguatan kompetensi dosen dalam pembelajaran berbasis student center learning. Pada sisi sarana dan prasarana menunjang keberhasilan proses pendidikan.

\section{DAFTAR PUSTAKA}

Syahruddin, dkk. Teachers' Pedagogical Competence in School-Based Management: A Case Study in a Public Secondary School at Pare-Pare, Indonesia. Journal of Education and Learning, Vol. 7 (4), pp. 213-218. .2013 .

Ahmad and Setyaningsih. Teacher Professionalism: A Study on Teachers' Professional and Pedagogic Competence at Junior, Senior, and Vocational High Schools in Banyumas Regency, Central Java, Indonesia. In Sosiohumanika, Jurnal Pendidikan sain sosial dan Kemanusiaan, Vol.5, No.1. 2012.

Caraka Putra Bhakti, dkk. Kemampuan Komunikasi Pedagogik Guru SMA Di Maluku Utara. Prosiding "The 6th International Conference on Educational, Management, Administration and Leadership (6th ICEMAL 2016). Bandung : 28 Agustus 2016.

Azhar. 2009. Kondisi LPTK sebagai pencetak guru yang profesional. JURNAL TABULARASA PPS UNIMED Vol.6 No.1, Juni 2009.

Azhar. 2011. Jurnal Tabularasa PPS UNIMED. Paradigma Meningkatkan Mutu Pendidikan Pada LPTK. Vol.8 No.1 Juni 2011.

Denise Vaillant (2013), "Teacher Education Programmes: Learning From Worldwide Inspiring Experiences". Journal Of Supranational Policies Of Education,. Volume 02, NO. 1, www.jospoe-gipes.com 
Endrotomo, 2013.Model - Model Pembelajaran Student Centered Learning. Makalah. Disampaikan pada Workshop Kurikulum Pendidikan Tinggi di Universitas Ahmad Dahlan, 27 November 2013

Harsono. 2008. Student-Centered Learning di Perguruan Tinggi. Vol. 3. No.1. Maret 2008. Jurnal Pendidikan Kedokteran dan Profesi Kesehatan Indonesia

Intan, Ahmad.2016. Arah \& Kebijakan Kementerian Riset, Teknologi, dan Pendidikan Tinggi : Kurikulum dan Sistem Pembelajaran LPTK. Makalah Disampaikan di Konferensi Nasional Pendidikan (KONASPI) ke VIII di Universitas Negeri Jakarta. 14 Oktober 2016

Kemendikbud, 2016. 7 Provinsi Raih Nilai Terbaik Uji Kompetensi Guru 2015. http://www.kemdikbud.go.id/main/blog/2016/01/7provinsi-raih-nilai-terbaik-uji-kompetensi-guru-2015

Mulyasa, E. (2005). Menjadi guru profesional. Bandung: PT Remaja Rosdakarya.

Peraturan Pemerintah RI Nomor 19 Tahun 2005 tentang Standar Nasional Pendidikan.

Peraturan Pemerintah No. 74 Tahun 2008 tentang Guru

Peraturan Presiden Nomor 8 tahun 2012, tentang Kerangka Kualifikasi Nasional Indonesia (KKNI)

Permenristekdikti No. 44 Tahun 2015 tentang Standar Nasional Pendidikan Tinggi

Rose, Colin dan Maclom J.Nicholl. 2002. Accelerated Learning For The 21st Century. Bandung Penerbit Nuansa.

Sailaja Chennat, 2014, "Internship In Pre-Service Teacher Education Programme: A Global Perspective". Australian Journal of Teacher Education. Volume 15, No. 1, www.impactjournals.us.

Saleha Parveen, 2012, " Internship Program in Education: Effectiveness, Problems and Prospects". International Journal of Learning \& Development. Volume 2, No. http://dx.doi.org/10.5296/ijld.v2i1.1471

Totok Bintoro.2014. Pengembangan Kurikulum LPTK \& Kaitannya Dengan KKNI. Makalah. Disampaikan pada Lokakarya Disain Kurikulum LPTK Berkelanjutan PPG dengan Mengacu KKNI di Universitas Muhammadiyah Surakarta, 10 April 2014

Winarno Surakhmad, dkk. 2003. Mengurai Benang Kusut Pendidikan.Jakarta:Transformasi.

Undang-Undang Nomor 12 Tahun 2012 tentang Pendidikan Tinggi 